\title{
Strategiczna odporność kraju i rola w niej podmiotów niepaństwowych
}

\section{Streszczenie}

Artykuł traktuje o możliwości wzmocnienia bezpieczeństwa Polski przez ustanowienie systemu strategicznej odporności kraju na agresję. Omawia takie przedsięwzięcia, jak: działania nieregularne na terytorium zajętym przez przeciwnika; wsparcie wojsk operacyjnych przez obronę terytorialną; przygotowywanie rezerw mobilizacyjnych; operacyjne przygotowanie terytorium kraju i ochrona obiektów infrastruktury krytycznej; bezpieczeństwo obywateli i struktur państwa, w tym powszechna ochrona ludności; powszechna edukacja dla bezpieczeństwa, w tym obronne przygotowanie społeczeństwa. Podkreśla się rolę udziału organizacji pozarządowych i podmiotów prywatnych w zapewnianiu strategicznej odporności kraju, wskazując na uwarunkowania prawne, finansowe, organizacyjne i historyczne.

Słowa kluczowe: Strategiczna odporność kraju, ochrona obiektów infrastruktury krytycznej, organizacje pozarządowe, podmioty prywatne

1 Prof. dr hab. Stanisław Koziej - generał brygady w stanie spoczynku, w latach 2010-2015 szef Biura Bezpieczeństwa Narodowego. W latach 2005-2006 podsekretarz stanu w Ministerstwie Obrony Narodowej, w 2007 roku - doradca Rzecznika Praw Obywatelskich, w 2008 roku - doradca Ministra Obrony Narodowej. Wieloletni nauczyciel akademicki, aktualnie profesor w Uczelni Łazarskiego w Warszawie (e-mail: stanislaw@koziej.pl). 


\title{
STANISŁAW KOZIEJ
}

\section{Strategic Resilience of the Country and the Role of the Nongovernmental Organisations}

\begin{abstract}
The article deals with the possibility of strengthening Polish security by establishing strategic system resilience the country's aggression. Discusses the enterprise such as irregular activities in the territory occupied by enemy; support operational troops by territorial defence; preparation of mobilizing reserves; the operational preparation of the country's territory and protection of the critical infrastructure objects; security of citizens and the State structures, including the common civil protection; universal education for security, including the preparation of the defence of society. The article emphasises the role of the participation of non-governmental organisations and private entities in the provision of strategic resistance country, pointing to the legal, financial, organisational and historical circumstances.
\end{abstract}

Keywords: strategic resilience of the country, protection of the critical infrastructure objects, nongovernmental organisations, private entities 
S ystem obronności kraju to coś więcej niż tylko siły zbrojne. Doskonalenie tego systemu zatem to coś więcej niż rozwój, transformacja, modernizacja armii. Konieczne jest zaangażowanie $\mathrm{w}$ to zadanie pozamilitarnych struktur państwa, a także organizacji niepaństwowych: prywatnych, społecznych i indywidualnych obywateli. Tylko w ten sposób można zapewnić to, co dla obrony ma wartość szczególną, a mianowicie strategiczną odporność kraju na ewentualną agresję. W świetle wniosków z niebezpiecznego konfliktu w naszej części Europy, w pobliżu naszych granic, w tym dotyczących tzw. działań hybrydowych, a zwłaszcza agresji poniżej progu otwartej, regularnej wojny (agresji podprogowej) ${ }^{2}$, taki system działań zwiększających strategiczną odporność Polski staje się pilną koniecznością. Tym bardziej, gdy weźmiemy pod uwagę, że w rezultacie konfrontacyjnej polityki Rosji ${ }^{3}$ wkraczamy, o ile już nie wkroczyliśmy, w okres nowej zimnej wojny.

Warto zaznaczyć, że strategiczna odporność kraju na agresję, na którą składają się działania militarne i niemilitarne - zwiększające niedostępność terytorium, powszechność przygotowań obronnych struktur pozamilitarnych, a także skuteczność wsparcia sił zbrojnych, w tym możliwość zorganizowanego oporu na terenach zajętych przez agresora - jest nie tylko jednym z ważnych elementów systemu obrony państwa, ale także jednocześnie istotnym czynnikiem odstraszania.

5 listopada 2014 roku Prezydent Rzeczypospolitej Polskiej Bronisław Komorowski podpisał nową Strategię Bezpieczeństwa Narodowego RP - nadrzędną koncepcję w systemie dokumentów strategicznych w dziedzinie bezpieczeństwa. Motywem przewodnim strategii jest kompleksowe, zintegrowane podejście do spraw bezpieczeństwa narodowego w wymiarze zewnętrznym i wewnętrznym, militarnym i pozamilitarnym ${ }^{4}$.

Obok zadań bezpieczeństwa dla podmiotów państwowych w Strategii przewidziano również istotną rolę i miejsce dla pozarządowych organizacji i stowarzyszeń oraz podmiotów prywatnych. W dokumencie tym zawartych jest 12 konkretnych odniesień, które w sposób bezpośredni lub pośredni dotyczą tej właśnie problematyki.

2 Zob. np. debata na ten temat podczas konferencji w Akademii Obrony Narodowej 16.04.2015 r., https://www.youtube.com/watch?v=C2_-G93LqeU.

3 Zob. np. wystąpienie prezydenta W. Putina w Soczi podczas dyskusji w Klubie Wałdajskim: Meeting of the Valdai International Discussion Club, October 22, 2015; http://en.kremlin.ru/events/president/ news $/ 50548$.

4 Zob. Strategia Bezpieczeństwa Narodowego, Warszawa 2015, http://www.bbn.gov.pl/ftp/SBN\%20RP.pdf. 
Strategia przywołuje potrzebę budowy systemu strategicznej odporności kraju na wszelkiego rodzaju zagrożenia oraz budowy systemu powszechnego bezpieczeństwa terytorialnego, $\mathrm{w}$ ramach których organizacje pozarządowe miałyby do odegrania istotną rolę. Strategia zakłada również stworzenie ram stosownego współdziałania między państwem a organizacjami sektora pozarządowego. Głównym celem zacieśnienia tej współpracy powinno być skoncentrowanie i skoordynowanie wysiłków podmiotów rządowych i pozarządowych, zarówno w wymiarze ludzkim, jak i w wymiarze zasobowym (materialnym).

Pamiętajmy, że ważną rolę w definiowaniu zadań dla tzw. trzeciego sektora powinny pełnić same organizacje pozarządowe. Państwo nie może być w tym względzie regulatorem. Pozarządowy i dobrowolny charakter działalności organizacji i stowarzyszeń proobronnych narzuca oczywiste ograniczenia. Państwo powinno być raczej koordynatorem, podpowiadającym i zachęcającym te podmioty do poszukiwania swojej roli, misji i zadań na rzecz bezpieczeństwa państwa.

Z drugiej strony - i to również powinno być kardynalną zasadą - nie możemy tworzyć „wojska poza wojskiem”. Myślę, że co do tego zaczyna panować coraz szersza zgoda, że już definitywnie odrzuca się tego typu pomysły, które gdzieniegdzie wcześniej się pojawiały. Osobiście uważam, że wskazane byłoby nadanie ostatecznej ofercie skierowanej do organizacji i stowarzyszeń proobronnych otwartego, inkluzywnego charakteru. Zbyt formalna, narzucająca nadmierne ograniczenia propozycja poszerzonej współpracy z organami państwa mogłaby studzić społeczny zapał, a nie o to przecież chodzi. Powinniśmy starać się uczynić formułę przyszłej poszerzonej współpracy interesującą i porównywalnie korzystną dla obu stron: rządowej i pozarządowej. To jeden z warunków powodzenia w realizacji tego potrzebnego zadania.

Społeczne oczekiwanie oraz sytuacja bezpieczeństwa skłaniają do podejmowania w miarę szybkich kroków w ramach istniejącego prawa, ale w dłuższym horyzoncie czasowym i w uzasadnionych przypadkach nie należy wykluczać możliwości zmiany niektórych przepisów, o co już wnoszą niektóre organizacje. Głośne są np. apele o zmianę prawa regulującego dostęp Polaków do broni.

Nowa formuła współdziałania państwa i organizacji oraz stowarzyszeń proobronnych powinna w jeszcze większym stopniu uwzględniać zintegrowany charakter bezpieczeństwa narodowego ${ }^{5}$. Oznacza to potrzebę znacznie szerszego włączenia pozostałych resortów zarówno w definiowanie potrzeb państwa, jak

Szeroko na ten temat mówi się w Białej Księdze Bezpieczeństwa Narodowego, prezentującej rezultaty pionierskiego w Polsce przedsięwzięcia z zakresu studiów strategicznych, jakim był pierwszy Strategiczny Przegląd Bezpieczeństwa Narodowego. Zob. Biała Księga Bezpieczeństwa Narodowego, BBN, Warszawa 2013; http://www.spbn.gov.pl/. 
i realne wspieranie działalności organizacji i stowarzyszeń. Wydaje się, że finalnie formuła współpracy $\mathrm{w}$ dziedzinie obronności mogłaby przyjąć formę ponadresortowego programu rządowego, obejmującego nie tylko sprawy obronności, czyli kompleksu cywilno-wojskowego, ale szerszą problematykę, którą określamy bezpieczeństwem narodowym.

Spójrzmy więc nieco bliżej na skład i strukturę systemu strategicznej odporności kraju na agresję oraz funkcje realizowane w jego ramach. Co on obejmuje i jakie stoją przed nim główne zadania?

Najogólniej rzecz biorąc, strategiczna odporność kraju to jego zdolność do oporu i przetrwania agresji poprzez: a) obronne przygotowanie społeczeństwa (świadomość obronna, patriotyczna narodu, umiejętności zachowania się w obliczu agresji zbrojnej); b) zwiększanie niedostępności operacyjnej terytorium (operacyjne przygotowanie terytorium, bezpieczna infrastruktura); c) działania nieregularne i wspierające różnych struktur państwowych wzmacniające działania regularne wojsk operacyjnych ${ }^{6}$.

Ideą systemu jest skoordynowanie różnych działań (legislacyjnych, operacyjnych, szkoleniowych, organizacyjnych, technicznych itp.) w wielu sektorach bezpieczeństwa mające służyć zwiększeniu strategicznej odporności kraju na zagrożenia, jako jednemu z ważnych wymiarów współczesnego odstraszania (powstrzymywania, odstręczania), w tym także przed próbami „miękkiej”, asymetrycznej agresji. Należą do nich przede wszystkim:

$\square$ działania nieregularne na terytorium zajętym przez przeciwnika (jako jedna z funkcji państwa podziemnego),

$\checkmark$ militarne wsparcie wojsk operacyjnych w działaniach regularnych (obrona terytorialna);

$\square$ przygotowywanie rezerw mobilizacyjnych,

$\square$ operacyjne przygotowanie terytorium kraju i ochrona obiektów infrastruktury krytycznej,

$\square$ bezpieczeństwo obywateli i struktur państwa, w tym powszechna ochrona ludności,

$\square$ powszechna edukacja dla bezpieczeństwa, $\mathrm{w}$ tym obronne przygotowanie społeczeństwa.

Stosownie do tych działań powinny zostać określone zadania dla poszczególnych podmiotów, takich jak wojska specjalne, zreformowane Narodowe Siły Rezerwowe,

6 Wg (MINI)SŁOWNIK BBN. Propozycje nowych terminów z dziedziny bezpieczeństwa; https:// www.bbn.gov.pl/pl/bezpieczenstwo-narodowe/minislownik-bbn-propozy/6035,MINISLOWNIKBBN-Propozycje-nowych-terminow-z-dziedziny-bezpieczenstwa.html?search=19841680. 
niewojskowe formacje bezpieczeństwa i ochrony ludności czy pozarządowe organizacje proobronne. To także zadania związane z doskonaleniem systemu rezerw mobilizacyjnych.

Prowadzenie oraz organizowanie działań nieregularnych na terytorium zajętym przez przeciwnika powinno być realizowane przede wszystkim przez Wojska Specjalne. Nie ma dziś miejsca na myślenie o tym w kategoriach dawnych, tradycyjnych formacji partyzanckich. W związku z tym rozważyć należy ukierunkowanie Wojsk Specjalnych zadaniowo na obronę kraju, zwiększenie ich liczebności oraz organizowanie szkolenia ich na terytorium kraju z pozostałymi strukturami państwa.

Zadaniem Narodowych Sił Rezerwowych, jako jednocześnie zalążków organizacyjnych dla rozwijania na czas wojny formacji obrony terytorialnej, powinno być lokalne wspieranie działań wojsk operacyjnych i innych sił bezpieczeństwa, a także stosowne uczestniczenie $\mathrm{w}$ działaniach nieregularnych na terytorium opanowanym przez przeciwnika. Przygotowanie do realizacji tego zadania powinno opierać się na zreformowaniu NSR tak, aby stanowiły one odrębne formacje przy jednostkach wojskowych, przewidziane w operacyjne podporządkowanie Wojewódzkich Sztabów Wojskowych („wojsko wojewodów”), oraz aby w ich skład wchodzili przede wszystkim rezerwiści, a nie jak obecnie kandydaci do służby zawodowej.

Konieczne jest przygotowanie systemu rezerw mobilizacyjnych umożliwiających strategiczne rozwinięcie sił zbrojnych do wielkości i struktury czasu wojny oraz ich uzupełnianie w toku działań wojennych. Do zadań w tym zakresie należałoby odpowiednie zaplanowanie potrzeb mobilizacyjnych, zorganizowanie zasobów mobilizacyjnych oraz szkolenie rezerw mobilizacyjnych.

Zapewnianie bezpieczeństwa struktur państwa, obywateli i infrastruktury krytycznej przed zagrożeniami zbrojnymi zapewniać powinny niewojskowe formacje bezpieczeństwa. Wiąże się to z koniecznością odpowiedniego określenia zadań oraz przygotowania Policji, służb specjalnych, straży samorządowych czy również agencji ochroniarskich i formacji ochrony obiektów.

Za ochroną ludności cywilnej przed skutkami zagrożeń militarnych i niemilitarnych w czasie wojny powinny odpowiadać określone formacje ochrony ludności. Zadania preparacyjne na tym obszarze powinny polegać m.in. na stworzeniu systemu ratowniczego z udziałem takich służb, jak Państwowa Straż Pożarna czy pogotowie ratunkowe, wykorzystanie w systemie ratownictwa Ochotniczych Straży Pożarnych oraz stworzenie struktur Obrony Cywilnej na czas wojny.

Istotną rolę w systemie powinny pełnić społeczne organizacje proobronne (stowarzyszenia, klasy mundurowe, grupy rekonstrukcyjne) oraz prywatne podmioty realizujące zadania kształtowania obywateli i społeczności lokalnych na 
rzecz bezpieczeństwa państwa oraz przygotowania ich do działania w warunkach zagrożenia i wojny, w tym realizacji powinności obronnych.

Włączenie organizacji pozarządowych do wzmacniania strategicznej odporności kraju było w ostatnim czasie przedmiotem szerokiego zainteresowania społecznego i dyskusji eksperckich oraz narad instytucjonalnych. Wiele takich debat organizowałem np. w Biurze Bezpieczeństwa Narodowego w ramach Strategicznego Forum Bezpieczeństwa. Najogólniejsze wnioski z nich dadzą się ująć $\mathrm{w}$ formie następujących punktów:

1. Uwarunkowania prawne. Istniejące regulacje prawne pozwalają znacznie rozszerzyć wykorzystanie organizacji pozarządowych bez daleko idących zmian ustawowych. Chodzi tu zwłaszcza o Ustawę z dnia 21 listopada 1967 r. o powszechnym obowiązku obrony Rzeczypospolitej Polskiej ${ }^{7}$ oraz Ustawę z dnia 24 kwietnia 2003 r. o działalności pożytku publicznego i o wolontariacie ${ }^{8}$. Wystarczające (na obecnym etapie) regulacje zawierają również ustawy: z dnia 18 kwietnia $2002 \mathrm{r}$. o stanie klęski żywiołowej, z dnia 26 kwietnia 2007 r. o zarządzaniu kryzysowym, z dnia 24 sierpnia 1991 r. o ochronie przeciwpożarowej, z dnia 21 czerwca $2002 \mathrm{r}$. o stanie wyjątkowym oraz z dnia 27 kwietnia 2001 r. Prawo ochrony środowiska9 Pojawiały się też wnioski co do rozszerzenia i uzupełnienia aktów wykonawczych, np. uszczegółowienia rozporządzenia Rady Ministrów z dnia 13 stycznia 2014 roku w sprawie ogólnych zasad wykonywania zadań w ramach powszechnego obowiązku obrony ${ }^{10}$. W dalszej perspektywie - w miarę doskonalenia współdziałania z organizacjami pozarządowymi - zmiany ustawowe, poprzedzone stosownym przeglądem obowiązujących aktów prawnych, wydają się być konieczne. Dotyczyć to może np. kwestii rozsądnego, uzasadnionego realnymi potrzebami rozszerzenia i ułatwienia kwalifikowanego dostępu do broni (co postulują niektóre organizacje pozarządowe), jak również szczegółowych kompetencji w poszczególnych obszarach wsparcia państwa przez NGO.

2. Uwarunkowania finansowe. Zwiększenie zaangażowania organizacji pozarządowych we wzmacnianie Strategicznej Odporności Kraju wymaga zwiększenia środków finansowych przeznaczanych na ten cel. Skalę potrzeb ilustruje przykład MON: Minister Obrony Narodowej na realizację zadań publicznych w 2014 roku zaplanował kwotę $8 \mathrm{mln} 920$ tys. zl, podczas gdy organizacje pozarządowe złożyły 703 oferty na kwotę ponad $27 \mathrm{mln}$ złotych. W 2013 roku podmioty zainteresowane pozyskaniem zbędnego w Siłach Zbrojnych RP mienia ruchomego Skarbu Państwa

\footnotetext{
7 Tekst jednolity Dz.U. z 2012 r., poz. 461 ze zm.

8 Dz.U. z 2003 r. Nr 96, poz. 873.

$9 \quad$ Dz.U. z 2001 r. Nr 62, poz. 627.

10 Dz.U. Nr 16, poz. 152.
} 
złożyły 906 wniosków z czego pozytywnie rozpatrzono 407. Łączna wartość przekazanego mienia wojskowego wyniosła 16643891,29 zł. Do tego dochodzą koszty eksploatacyjne, związane z użyczeniem obiektów i sprzętu (np. koszty transportu).

Należy jednak zauważyć, że dotychczasowe plany współpracy MON z organizacjami pozarządowymi koncentrowały się na przedsięwzięciach promujących obronność, a nie budujących konkretne zdolności wspierające siły zbrojne lub wzmacniające strategiczną odporność kraju na ewentualną agresję. Zmiana struktury rocznych planów współpracy - a tym samym propozycji dla organizacji pozarządowych w ramach otwartych konkursów ofert na zlecanie zadań publicznych w zakresie obronności państwa - to najprostszy sposób zmiany charakteru współpracy wojsko-organizacje w kierunku wzmacniania strategicznej odporności kraju.

3. Doświadczenia historyczne. Już w czasach II Rzeczypospolitej-pod wpływem doświadczeń I wojny światowej - zdecydowano o wykorzystaniu organizacji pozarządowych (paramilitarnych, proobronnych i kombatanckich) do odpowiedniego przygotowania obronnego całego społeczeństwa oraz stworzenia systemu rezerw osobowych na potrzeby mobilizacyjne. Organizacje te prowadziły działalność zgodnie z wytycznymi wojska, a nadzór i koordynację przygotowania obronnego społeczeństwa i edukacji obronnej sprawował Państwowy Urząd Wychowania Fizycznego i Przysposobienia Wojskowego (PUWFiPW) utworzony w 1927 roku przez władze wojskowe. Z kolei związki rezerwistów skupiała Federacja Polskich Związków Obrońców Ojczyzny (FPZOO) utworzona w 1928 roku. Warto przypomnieć, że organizacje jej podległe miały często własne, niezależne od wojska pomysły tworzenia samodzielnych formacji na czas wojny. W latach 30. FPZOO przedstawiła np. koncepcję samodzielnego wystawienia "armii rezerwowej” - z własną kadrą dowódczą i zadaniami, „dopuszczając” jej podporządkowanie regularnemu wojsku" ${ }^{11}$.

4. Uwarunkowania formalno-organizacyjne. Różnorodność organizacji pozarządowych daje szanse wykorzystania ich potencjału w ramach wzmacniania bezpieczeństwa państwa zarówno w sferze działań niemilitarnych, w tym pośrednich (oddziaływanie na społeczeństwo), i bezpośrednich (realizowanych na rzecz sił zbrojnych) oraz militarnych (operacyjnych).

W sferze działań niemilitarnych, $w$ tym przede wszystkim pośrednich, potencjał, jakim dysponują organizacje pozarządowe, jest wykorzystywany od wielu lat. Działania resortu obrony narodowej w tym zakresie reguluje decyzja nr 187/ MON Ministra Obrony Narodowej z dnia 9 czerwca 2009 r. ${ }^{12}$. Obowiązujące przepisy prawa, w szczególności zapisy rozporządzenia Rady Ministrów z dnia 13 stycznia 2004 r. w sprawie ogólnych zasad wykonywania zadań w ramach powszechnego

\footnotetext{
11 L. Wyszczelski, Armia Rezerwowa II Rzeczypospolitej, Warszawa 2014.

12 Dz.Urz. MON z 2009 r. Nr 12, poz. 131 ze zm.
} 
obowiązku obrony ${ }^{13}$, pozwalają na wykorzystanie potencjału organizacji społecznych do realizacji zadań obronnych. Możliwość taką posiada w swych kompetencjach wojewoda, który w planie operacyjnego funkcjonowania może wskazać konkretną organizację do realizacji zadania obronnego jako podmiot współdziałający. Realizacja takiego przedsięwzięcia wymaga podpisania stosownego porozumienia.

Do chwili obecnej potencjał pozarządowych organizacji proobronnych w sferze bezpośrednich działań niemilitarnych nie był wykorzystywany, a w sferze działań militarnych (operacyjnych) nie rozważano nawet opcji jego wykorzystania.

W odniesieniu do dotychczasowych kierunków prac należy zaznaczyć, że:

operacyjne (bojowe) wykorzystanie potencjału pozarządowych organizacji proobronnych łączy się z potrzebą włączenia ich w struktury wojskowe (jako samodzielnych formacji lub elementów większej całości);

- Narodowe Siły Rezerwowe (NSR), które, ściśle współpracując z organizacjami proobronnymi, mogłyby stanowić bazę do rozwijania na czas wojny formacji obrony terytorialnej, stanowią część Sił Zbrojnych RP, które funkcjonują w ramach jednolitego systemu dowodzenia i kierowania, zaopatrywania, uzupełnień, a także innych podsystemów wykonawczych, posiadają określoną liczebność i strukturę oraz szkolone są zgodnie z obowiązującymi dokumentami doktrynalnymi;

- ewentualne włączenie dodatkowych elementów w strukturę Narodowych Sił Rezerwowych wiązałoby się z koniecznością dostosowania ich do obowiązujących w Siłach Zbrojnych wymogów w celu osiągnięcia odpowiedniego poziomu interoperacyjności, $\mathrm{w}$ tym również ujednolicenia i skonsolidowania procesu kierowania i szkolenia;

wykorzystanie potencjału pozarządowych organizacji proobronnych w sferze działań militarnych (operacyjnych, bojowych) wymaga uwzględnienia takich czynników, jak: określenie formuły współdziałania (włączenie w struktury militarne czy tylko ich wspieranie), zapewnienie kompatybilności struktur i systemu kierowania, ujednolicenie wyposażenia i logistycznego zaopatrywania, skonsolidowanie procesu szkolenia, zapewnienie finansowania, wskazanie organu administracji sprawującego nadzór;

z z punktu widzenia Sił Zbrojnych RP najbardziej pożądana byłaby formuła współpracy z jednym partnerem społecznym (np. zrzeszeniem pozarządowych organizacji proobronnych), której celem będzie wspieranie działań elementów militarnych systemu obronnego;

13 Dz.U. z 2004 r. Nr 16, poz. 152. 
w ramach nowego cyklu planowania obronnego przewiduje się wykorzystanie kompetencji wojewodów w zakresie nakładania zadań obronnych na organizacje pozarządowe na szczeblu lokalnym (województwa) przy założeniu, że ich realizacja będzie zgodna ze statutem organizacji, odbywać się będzie na obszarze jej działania i w oparciu o stosowne porozumienia, zarówno w przypadku zaistnienia sytuacji kryzysowych wynikających z zagrożeń niemilitarnych (szczególnie o znamionach klęsk żywiołowych), jak również w sytuacji zewnętrznego zagrożenia i w czasie wojny.

W dalszych pracach na rzecz włączania podmiotów pozarządowych do działań na rzecz wzmacniania strategicznej odporności kraju należałoby uwzględnić szereg szczegółowych problemów sygnalizowanych przez te podmioty. Warto tu wskazać np. na:

trudności w weekendowym dostępie do obiektów szkoleniowych (niestety, wojsko ma wówczas „wolne");

$\square$ rozliczanie nieobecności $w$ pracy osób biorących udział w działaniach antykryzysowych (dotyczy to zwłaszcza krótkofalowców, zabezpieczających łączność, informowanie i powiadamianie - w ramach reagowania kryzysowego);

$\square$ szersze uwzględnianie (zapraszanie) NGO do udziału w ćwiczeniach i manewrach;

częstsze korzystanie z formuły powierzania, a nie zlecania zadań.

Podsumowując, można wskazać na kilka generalnych wniosków z prowadzonych dotąd rozważań.

Niewątpliwie należy dokonać przeglądu aktów prawnych w celu zidentyfikowania obszarów niezbędnych zmian (chodzi zwłaszcza o sztuczne ograniczenia oraz wyeliminowanie ewentualnych sprzeczności odnośnie do postrzegania roli NGO).

Należy też przeanalizować zakres i mechanizm dozwolonego prawem reklamowania członków organizacji pozarządowych (wyłączenia - w uzasadnionych przypadkach - z mobilizacji w ramach powszechnego obowiązku obrony). Reklamowanie powinno jednak nadal pozostać wyjątkiem, a nie regułą.

Warto bliżej zidentyfikować przypadki, w których współpraca z organizacjami - ze względu na szczególne znaczenie dla obronności - powinna mieć charakter niejawny i rozpocząć prace nad odpowiednimi regulacjami prawnymi.

I wreszcie - zakres tematyczny rocznych planów współpracy MON z organizacjami pozarządowymi powinien być poszerzony tak, aby większy nacisk (i przeznaczenie proporcjonalnie większych środków) był położony na przedsięwzięcia 
o największym znaczeniu dla wzmacniania strategicznej odporności kraju na ewentualną agresję.

I na koniec: warto jeszcze raz podkreślić, że zwiększenie zaangażowania NGO we wzmacnianie strategicznej odporności kraju nie może oznaczać tworzenia „wojska poza wojskiem”. Siła zbrojna musi pozostać w wyłącznej kompetencji państwa.

\section{Bibliografia}

Biała Księga Bezpieczeństwa Narodowego, BBN, Warszawa 2013; http://www.spbn.gov.pl/.

Meeting of the Valdai International Discussion Club, October 22, 2015; http://en.kremlin.ru/events/president/news/50548.

(Mini)słownik BBN. Propozycje nowych terminów z dziedziny bezpieczeństwa; https://www.bbn.gov.pl/pl/bezpieczenstwo-narodowe/minislownik-bbn-propozy/6035,MINISLOWNIK-BBN-Propozycje-nowych-terminow-z-dziedziny-bezpie czenstwa.html?search $=19841680$.

Strategia Bezpieczeństwa Narodowego, Warszawa 2015, http://www.bbn.gov.pl/ftp/SBN\%20RP.pdf.

Wojna hybrydowa i agresja poniżej progu wojny, konferencja w Akademii Obrony Narodowej 16.04.2015 r., https://www.youtube.com/watch?v=C2_-G93LqeU.

Wyszczelski L., Armia Rezerwowa II Rzeczypospolitej, Warszawa 2014. 